\title{
Familial Polycythaemia Caused by a New Haemoglobin Variant: Hb Heathrow, $\beta$ I03 (G5) Phenylalanine $\rightarrow$ Leucine
}

\author{
J. M. WHITE, L. SZUR, I. D. S. GILLIES, P. A. LORKIN, H. LEHMANN
}

British Medical fournal, 1973, 3, 665-667

\section{Summary}

A new variant of haemoglobin A ( $\mathrm{Hb}$ A) with a high affinity for oxygen has been found in an English family. Five members are affected and all are polycythaemic. This variant (Hb Heathrow) is the first of this class to be found in this country and has the same electrophoretic mobility as Hb A. It was discovered only by measuring the oxygen affinity of the patients' red cells. This emphasizes the need for measuring the oxygen affinity of haemoglobin in patients with polycythaemia if other clinical and haematological features associated with polycythaemia rubra vera are absent.

\section{Introduction}

Charache et al. (1966) reported on a family in which several members were found to be polycythaemic and heterozygous for a haemoglobin variant (Hb Chesapeake $\propto 92 \mathrm{Arg}-\mathrm{Leu}$ ) which had a higher affinity for oxygen than $\mathrm{Hb}$ A. Subsequently, 11 other high affinity haemoglobins which cause familial polycythaemia have been discovered (Botha et al., 1966; Jones et al., 1967; Rucknagel et al., 1967; Reed et al., 1968; Adamson et al., 1969; Bronberg et al., 1971; Hayashi et al., 1971; Boyer et al., 1972; Stamatoyannopoulos et al., 1973; H. Ranney, personal communication, 1973). All except one, Hb Olympia (Stamatoyannopoulos et al., 1973), were separable from $\mathrm{Hb}$ A by electrophoresis.

We report the finding of such a haemoglobin variant in an English family (Hb Heathrow $\beta 103$ (G5) Phe-Leu). It is the first to be found in this country, and like $\mathrm{Hb}$ Olympia does not separate from $\mathrm{Hb}$ A by routine electrophoresis. Further, the mutation is unusual in that it does not obviously affect the subunit contacts of the haemoglobin molecule involved in the preservation of normal oxygen affinity, but occurs in the haem pocket. It is of much interest that this particular mutation in the haem pocket alters the residue in position (G5) back to that found in myoglobin.

\section{Methods \\ GENERAL METHODS}

Routine haemotological indices were measured using standard techniques (Dacie and Lewis, 1968). Haemoglobin electro-

Royal Postgraduate Medical School, London W12 0HS

J. M. WHITE, M.B., CH.B., Consultant Haematologist, Department of Haematology

L. SZUR, M.B., F.F.R., Consultant, Department of Radiotherapy

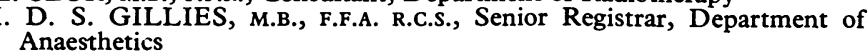

M.R.C. Abnormal Haemoglobin Unit, University Department of Biochemistry, Addenbrooke's Hospital, Cambridge CB2 2QR

P. A. LORKIN, B.A., Member of Scientific Staff

H. LEHMANN, M.D., F.R.C.P., F.R.S., Honorary Director phoresis was carried out on starch gel at pH 8.6 (Smithies, 1959). The red cell and plasma volumes were determined using ${ }^{51} \mathrm{Cr}$ and ${ }^{125} \mathrm{I}$-human serum albumin. The oxygen affinity of the haemoglobin was measured using whole red cells at $\mathrm{pH} 7 \cdot 4$ (Bellingham and Huehns, 1968). The $\alpha$ - and $\beta$-chains of the haemoglobin were separated according to the method of Clegg et al. (1966) and preparative chromatograms and amino-acid analysis of the tryptic peptides of the chains were carried out using standard techniques (Lehmann and Huntsman, 1973).

\section{CARDIOVASCULAR STUDIES}

The purpose of these studies was explained to the patient and his permission was obtained. Catheters were introduced under local anaesthesia into the left radial artery and the right atrium. Arterial and central venous oxygen tensions were measured in a calibrated Clark electrode at $37^{\circ} \mathrm{C}$ and corrected for the patient's temperature and for the blood gas factor. The Astrup microequilibration technique was used to determine $\mathrm{PCO}_{2}$, standard bicarbonate, base excess, and non-respiratory $\mathrm{pH}$ (Stoker et al., 1972). Oxygen content was measured using the LEX $\mathrm{O}_{2} \mathrm{CON}$ analyser. Cardiac output was determined by the indicator dilution technique with indocyanine green and also by the Fick principle. Oxygen consumption was estimated by analysis of expired air.

\section{Case Report}

The propositus was a 62-year-old Englishman who was referred to the Hammersmith Hospital when he was found to have a haemoglobin level of $20 \mathrm{~g} / 100 \mathrm{ml}$ on routine testing before surgery.

His past medical history was of a myocardial infarction when aged 58 years, but since that time he has been well. On questioning he denied any history of angina or dyspnoea but stated that his daughters were found to have high haemoglobin levels during their pregnancies and that his mother and maternal grandfather (both now dead) were always plethoric.

On examination he showed the ruddy "cyanosis" of polycythaemia, with suffusion of the conjunctivae but nothing abnormal was found in any system. Notably his spleen was not palpable and no renal mass was felt. The haematological findings were as follows: $\mathrm{Hb} 21.0 \mathrm{~g} /$ $100 \mathrm{ml}$, packed cell volume (P.C.V.) $66 \%$, mean corpuscular haemoglobin $32 \mathrm{pg}$, reticulocytes $1 \cdot 2 \%$, W.B.C. $7,000 / \mathrm{mm}^{3}$ (normal differential), platelet count $260,000 / \mathrm{mm}^{3}$. The diagnosis of polycythaemia was confirmed by estimation of the red cell mass, which was $55 \mathrm{ml} / \mathrm{kg}$ (normal values for adult males $30 \pm 5 \mathrm{ml} / \mathrm{kg}$ ). The plasma volume was within normal limits at $42 \mathrm{ml} / \mathrm{kg}$. Since apart from the increased red cell volume he lacked the other features of polycythaemia rubra vera he was investigated for other possible causative factors. There was no clinical evidence of cerebellar tumour or hepatoma and the intravenous pyelogram was normal. No evidence of cardiovascular or pulmonary disease was found. His arterial $\mathrm{Po}_{2}$ was normal on two occasions (92 and $99 \mathrm{~mm} \mathrm{Hg}$ ). The analysis of his haemoglobin by routine electrophoresis showed only $\mathrm{Hb} \mathrm{A}$. The $\mathrm{Hb} \mathrm{\textrm {A } _ { 2 }}$ was $2.3 \%$ and $\mathrm{Hb} \mathrm{F}$ was $0.9 \%$. However, the oxygen affinity curve of his whole red cells (fig. 1) showed the characteristic findings of a high oxygen affinity haemoglobin resulting from an amino-acid mutation in the globin. The oxygen dissociation curve was markedly shifted to the left, the $\mathrm{P}_{50}{ }^{*}$ being $9.5 \mathrm{~mm} \mathrm{Hg}$ at $\mathrm{pH} 7.4$ (normal range 22-24 $\mathrm{mm} \mathrm{Hg}$ ). In addition there was a loss of haem-haem interaction,

${ }^{*} \mathrm{P}_{50}$ is the partial pressure of oxygen at which the haemoglobin is $50 \%$ saturated with oxygen. 
TABLE I-Haematological Indices of Affected and Non-affected Carriers of Hb Heathrow

\begin{tabular}{|c|c|c|c|c|c|c|c|c|c|}
\hline Case No. & $\begin{array}{l}\text { Age in } \\
\text { Years }\end{array}$ & Sex & Hb Heathrow & $\mathrm{Hb}(\mathrm{g} / 100 \mathrm{ml})$ & $\begin{array}{l}\text { Packed Cell } \\
\text { Volume (\%) }\end{array}$ & $\underset{(\%)}{\text { Reticulocytes }}$ & W.B.C. $/ \mathrm{mm}^{3}$ & Platelets $/ \mathrm{mm}^{3}$ & $P_{s o}(\mathrm{~mm} \mathrm{Hg})$ \\
\hline $\begin{array}{l}1 \\
2 \\
3 \\
4 \\
5 \\
6 \\
7 \\
8 \\
9\end{array}$ & $\begin{array}{c}62 \\
29 \\
27 \\
4 \frac{1}{2} \\
2 \\
58 \\
52 \\
4 \\
2 \frac{1}{2}\end{array}$ & $\begin{array}{l}\text { M. } \\
\text { F. } \\
\text { F. } \\
\text { F. } \\
\text { F. } \\
\text { M. } \\
\text { F. } \\
\text { F. } \\
\text { F. }\end{array}$ & $\begin{array}{l}+ \\
+ \\
+ \\
+ \\
+ \\
+ \\
= \\
-\end{array}$ & $\begin{array}{l}21 \cdot 0 \\
16.7 \\
16 \cdot 2 \\
16 \cdot 4 \\
15 \cdot 7 \\
14 \cdot 2 \\
14 \cdot 0 \\
13.0 \\
12 \cdot 2\end{array}$ & $\begin{array}{l}64 \\
52 \\
48 \\
52 \\
49 \\
45 \\
41 \\
40 \\
35\end{array}$ & $\begin{array}{l}0.2 \\
1.4 \\
1.0 \\
0.9 \\
0.8 \\
1.2 \\
1.0 \\
1.2 \\
1.0\end{array}$ & $\begin{array}{r}7,200 \\
10,000 \\
6,500 \\
12,200 \\
12,500 \\
7.800 \\
5,900 \\
9,700 \\
8,100\end{array}$ & $\begin{array}{l}260 \\
204 \\
220 \\
232 \\
200 \\
310 \\
295 \\
210 \\
260\end{array}$ & $\begin{array}{r}9.5 \\
10.0 \\
10.4 \\
10.0 \\
10.2 \\
22.8 \\
21 \cdot 6 \\
20.3 \\
21.5\end{array}$ \\
\hline
\end{tabular}

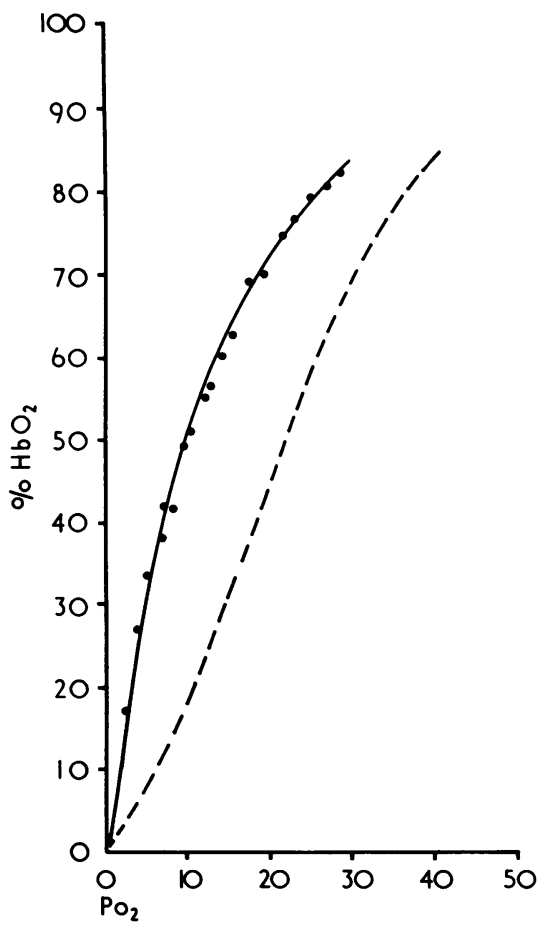
PIG. 1-Case 1 . Whole cell oxygen affinity curves $=5$
$\left(\mathbf{P}_{50}=9.5 \mathrm{~mm} \mathrm{Hg}\right)$ and normal control $---\left(\mathbf{P}_{50}=22 \mathrm{~mm}\right.$
$\mathbf{H g})$.

" $n "=1 \cdot 2$ (normal value $=3 \cdot 0$ ). The Bohr shift was at the lower limit of normal at 0.42 . The red cell concentration of 2,3-diphosphoglycerate was normal at $4.5 \mu \mathrm{mol} / \mathrm{ml}$ R.B.C. Subsequent analysis of his haemoglobin by starch gel electrophoresis at $\mathrm{pH} \mathrm{7.0,} \mathrm{DEAE-}$ Sephadex chromatography, and isoelectric focusing did not reveal any abnormal haemoglobin.

Family Studies.-Eight other members of his family were available for study. Four of them were found to be similarly affected as judged by high haemoglobin levels of $15 \cdot 7-16 \cdot 7 \mathrm{~g} / 100 \mathrm{ml}$ and oxygen affinity curves shifted to the left. The haematological data of affected and nonaffected members are shown in table I. All the affected subjects were asymptomatic.

Amino-acid Substitution.-Since no new haemoglobin or polypeptide chains could be separated from those of normal $\mathrm{Hb} \mathrm{A}$, the structural analysis was performed on the whole separated $\alpha$ - and $\beta$-chains. The peptide chromatograms did not show any new peptide spots in either position or staining. The amino-acid content of each peptide was therefore analysed. The amino-acid composition of all but one of the peptides examined- $\beta$ tryptic peptide (Tp) XI-was that of normal $\mathrm{Hb} \mathrm{A}$. However, in $\beta \mathrm{TpXI}$, which is comprised of residues $96-104$, less than one residue of phenylalanine ( $\beta 103)$ was present and an additional 0.35 residue of leucine was found (table II). The only explanation is that this peptide really consists of a mixture of two peptides, one of which has the normal phenylalanine side chain at position 103, while the other instead contains leucine in this position. As the side chains of phenylalanine and leucine have almost the same electrophoretic and chromatographic properties, the reason for the failure to separate by such methods the whole haemoglobins, the isolated $\beta$-chains, and the peptides becomes clear. Further chemical studies confirmed that the mutation was $\beta 103$ Phe-Leu.
TABle II-Amino-acid Composition of $\beta T p X I$ Peptide Prepared from Peptide Chromatograms of Amino-ethylated -Chain of Patient under study

\begin{tabular}{c|c|c}
\hline \multirow{2}{*}{ Amino-acid } & \multicolumn{2}{|c}{ Molar Ratio } \\
\cline { 2 - 3 } & Actual & Expected \\
\hline Asp & 1.96 & 2.0 \\
Glu & 0.99 & 1.0 \\
Pro & 0.87 & 1.0 \\
Val & 1.06 & 1.0 \\
Leu & 1.35 & 1.0 \\
Phe & 0.44 & 1.0 \\
Ars & 0.89 & 1.0 \\
Arg & 0.80 & 1.0
\end{tabular}
The finding of an extra 0.35 of a molar residue of leucine and a loss of 0.56 of a ing leucine and the other phenylalanine. Treatment of the peptide with carboxypeptides A + B confirmed that phenylalanine 103 (G5) was the one affected.

The Phe and Leu add up not to $2 \cdot 0$ residues but to 1.79 ; the deficiency is probably due to partial destruction of the $\mathrm{N}$-terminal residue on ninhydrin staining. In two further analyses of the peptide a combined total of $P$ he and Leu near to $2 \cdot 0$ residues was obtained.

On thermolysin digestion of the isolated $\beta \mathrm{TpXI}$ the expected fragments including the dipeptide Phe-Arg ( $\beta^{A}$ 103-104) were found, with one additional fragment. This consisted of leucine and arginine indicating that two tryptic peptides $\beta$ XI had been digested, one with Phe-Arg and the other with Leu-Arg as C-terminal residues. Treatment of the $\beta \mathrm{TpXI}$ with carboxypeptidases $\mathrm{B}$ and $\mathrm{A}$ released first arginine, and then both phenylalanine and leucine (see fig. 2).

Cardiovascular Studies. - At the time these investigations were performed the patient's haemoglobin had been reduced to $18.0 \mathrm{~g} /$ $100 \mathrm{ml}$ by venesection. The central venous oxygen tension was normal $(40.5 \mathrm{~mm} \mathrm{Hg})$ as was the arterial oxygen tension $(99 \mathrm{~mm} \mathrm{Hg})$. The mean value of six estimations of his cardiac output showed that it was raised to $3.71 . / \mathrm{min} / \mathrm{m}^{2}$. The arterial whole blood $\mathrm{pH}$ was 7.440 but the non-respiratory $\mathrm{pH}$ was low $(7 \cdot 310)$, indicating a metabolic acidosis.

\begin{tabular}{|c|c|c|c|c|c|c|c|c|}
\hline No. & 96 & 97 & 98 & 99 & 100 & 101 & 102 & 103 \\
\hline Hb A & Leu & His & Val & Asp & Pro & Glu & Asn & Phe \\
\hline
\end{tabular}

FIG. 2-Analysis of tryptic peptide (Tp) $\beta$ XI ( $\beta 96-104)$. Tryptic peptide $\beta X I$ normally yields three thermolysin fragments. Points of hydrolysis are indicated by vertical arrow $(\triangle)$. In this case an additional fragment Leu-Ar was obtained. In a tryptic peptide Arg must be the C-terminus, and the was obtained In a tryestic indicated by horizontal arrow (_)

\section{Discussion}

In the past three years major advances have been made in the understanding of the structural differences between the oxyand deoxy- conformation of haemoglobin (Perutz, 1970). Briefly, the transition from one state to the other requires the breaking or formation of salt ridges between the four chains or subunits of the haemoglobin molecule. The reason for the high oxygen affinity of $\mathrm{Hb}$ Heathrow is interesting. Phenylalanine (G5) is found in the $\alpha-, \beta-, \gamma-$, and $\delta$-chains of haemoglobin, where its side chain points into the haem pocket and contacts the haem plate. From examination of his atomic model of haemoglobin Perutz concluded that if this side chain is missing then the high oxygen affinity of $\mathrm{Hb}$ Heathrow could be the result of several factors. However, it is likely that the most important one would be that the haem plate might move into the position it adopts in the oxy- configuration. In deoxyhaemoglobin the phenylalanine chain at G5 supports the haem plate when it takes up a more upright position than in oxyhaemo- 
globin. The replacement of this important contact by the smaller side chain of leucine would make this change in tilt more difficult, and as a result the molecule would tend to have the conformation of oxyhaemoglobin rather than deoxyhaemoglobin. It is noteworthy that whereas phenylalanine in this position is invariant to the polypeptide chains of $\mathrm{Hb} \mathrm{A}$, leucine occupies this position in myoglobin, which is a high affinity haem-protein. One can understand why myoglobin (a monomer), unlike haemoglobin (a tetramer), has a hyperbolic rather than a sigmoid oxygen dissociation curve but this, in itself, only partly explains its high oxygen affinity. The finding of the same single mutation in $\mathrm{Hb}$ Heathrow might help to clarify this point.

\section{PHYSIOLOGICAL COMPENSATION}

The main functional implication of an oxygen affinity curve which is shifted markedly to the left is that it hinders the delivery of oxygen to the tissues. For a given fall in oxygen tension from arterial to venous blood $\mathrm{Hb}$ Heathrow will release much less oxygen than will normal $\mathrm{Hb} \mathrm{A}$. There are three mechanisms which could compensate for this-namely, an increase in the oxygen carrying capacity of the blood (that is, an increase in the haemoglobin concentration), an increase in the cardiac output, and an in vivo alteration of the position of the oxygen affinity curve by, for example, $\mathrm{pH}$. Assuming that no reduction of the intercapillary distance occurs in the tissues, then failure of these mechanisms to compensate fully for the leftward shift of the curve would result in tissue hypoxia and be reflected by a lowering of the mixed venous oxygen tension. In our patient the central venous oxygen tension was normal, implying adequate tissue oxygenation.

How far the raised haemoglobin concentration helps to increase the supply of oxygen to the tissues is shown in fig. 3 . The actual values for the arterial and central venous oxygen tensions measured in our patient are used. The curve on the right shows that in a subject with $\mathrm{Hb} \mathrm{A}$ at a concentration of $14.0 \mathrm{~g} / 100 \mathrm{ml}$ and a normal $P_{50}$ of $26 \mathrm{~mm} \mathrm{Hg}$ the arteriovenous oxygen content difference (excluding dissolved oxygen) 'would be about 4.8 volumes per $100 \mathrm{ml}$. The middle curve shows the hypothetical situation of a subject with the same concentration of haemoglobin but with a $P_{50}$ equal to that of our patient. The arteriovenous oxygen content difference would be about half. The curve on the left shows that the increased oxygen carrying capacity in our patient enables him to have a higher arterio-

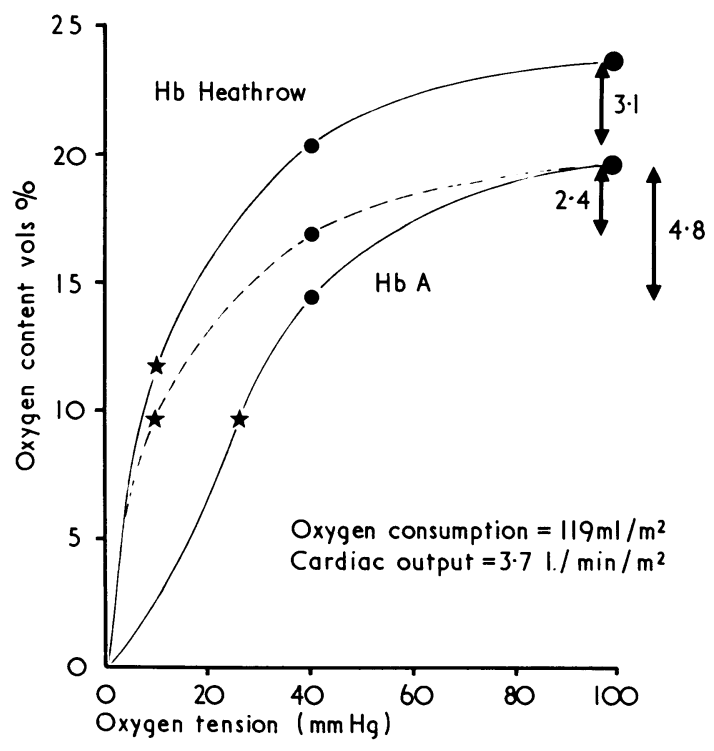

FIG. 3-Diagram showing how far increased oxygen carrying capacity contributes as a mechanism to compensate for high oxygen affinity of $\mathrm{Hb}$ Heathrow. $O=$ Arterial $\mathrm{O}_{2}$ content. $=$ Venous $\mathrm{O}_{2}$ content. $\star=\mathbf{P}_{50}$ of whole blood. For explanation see text. venous content difference for the same fall in oxygen tension. Nevertheless, even if the dissolved oxygen is included, this difference is still only 3.25 volumes per $100 \mathrm{ml}$ instead of the normal value of 5 volumes per $100 \mathrm{ml}$. The deficit appears to be made up by a raised level of his cardiac output. However, the low non-respiratory $\mathrm{pH}$ of his blood indicates a significant degree of anaerobic metabolism, which implies that, even at rest, the patient is incurring a small oxygen debt.

It should be added that, particularly in view of the history of myocardial infarction in this patient, it was felt that he would benefit from occasional venesection to reduce the P.C.V. to a level just below $60 \%$. The rationale for this is that above a P.C.V. of $60 \%$ the viscosity of the blood becomes markedly increased (Harris and Kellermeyer, 1970). Indeed, after venesection of two units he felt better. However, since our results indicate that the increase in red cell volume is one of the most important compensatory mechanisms for the high affinity of his haemoglobin, the benefit gained by its reduction remains to be assessed.

\section{FREQUENCY OF HIGH AFFINITY HAEMOGLOBINS}

About $15-20 \%$ of patients with polycythaemia rubra vera have a normal leucocyte count and platelet count, and the diagnosis is made by a process of exclusion of the various causes of secondary polycythaemia (Szur et al., 1959; Szur, 1972). In about a third of these patients there is also no clinical evidence of splenic enlargement and it is in this group in particular that a search for carriers of high affinity haemoglobin should be made. While at present abnormal haemoglobins are a very rare cause of secondary polycythaemia, it seems likely that their incidence is underestimated. This is well shown by the family reported here. It must be emphasized that routine electrophoresis is of limited use in that it does not measure the function of haemoglobin and it is therefore important that patients with an unexplained polycythaemia should have the oxygen affinity of their red cells measured.

We wish to thank Dr. P. A. Roberts and Dr. S. Varadi for referring the patient to us, and Miss B. Bird and Miss P. A. M. Kynoch for technical help.

\section{References}

Adamson, J. W., Parer, J. T., Stamatoyannopoulos, G., and Heinenberg, S. (1969). Fournal of Clinical Investigation, 48, 1376.

Bellingham, A. J., and Huehns, E. R. (1968). Nature, 218, 924.

Botha, M. C., Beale, D., Isaacs, W. A., and Lehmann, H. (1966). Nature, 212, 792 .

Boyer, S. H., et al. (1972). Fournal of Clinical Investigation, 51, 666.

Bronberg, P. A., Padilla, F., Guy, J. T., and Balcerzak, S. P. (1971). Clinical

Research, 19, 564 .
Charache, S., Weatherall, D. J., and Clegg, J. B. (1966). Fournal of Clinical Investigation, 45, 813

Clegg, J. B., Naughton, M. A., and Weatherall, D. J. (1966). Fournal of Molecular Biology, 19, 91 .

Dacie, J. V., and Lewis, S. M. (1968). Practical Haematology, 4th edn. London; Churchill.

Hamilton, H. B., Iuchi, I., Miyaji, T., and Shibata, S. (1969). Fournal of Clinical Investigation, 48, 525 .

Harris, J. W., and Kellermeyer, R. W. (1970). The Red Cell. Cambridge, Mass., Harvard University Press. Hayashi, A., Stamatoyannopoulos, G., Yoshida, A., and Adamson, J. (1971).
Nature New Biology, 230, 264.

Jones, R. T., Osgood, E. E., Brimhall, B., and Koler, R. D. (1967). Fournal

of Clinical Investigation, 46, 1840.
Lehmann, H., and Huntsman, R. G. (1973). Mans Haemoglobins, 2nd edn. Amsterdam, North Holland Publishing Company.

Perutz, M. F. (1970). Nature, 228, 726.

Reed, C. S., et al. (1968). Blood, 31, 623.

Rucknagel, D. L., Glynn, K. P., and Smith, J. R. (1967). Clinical Research, $15,270$.

Smithies, O. (1959). Biochemical fournal, 71, 589.

Stamatoyannopoulos, G., Nute, P. E., Adamson, J. W., Bellingham, A. J., Funk, D., and Hornung, S. (1973). Fournal of Clinical Investigation, 52, 342 .

Stoker, J. B., Kappagoda, C. T., Grimshaw, V. A., and Linden, R. J. (1972). Clinical Science, 42, 455.

Szur, L., Lewis, S. M., and Goolden, A. W. G. (1959). Quarterly fournal of Medicine, 28, 397.

Szur, L. (1972). In Tutorials in Postgraduate Medicine, ed. A. V. Hoffbrand and S. M. Lewis. London, Heinemann. 